\title{
Japanese Public Diplomacy in Indonesia: The Role of Japanese Agencies in Academic Exchange Programs between Japan and Indonesia
}

\author{
A. Safril Mubah \\ Universitas Airlangga
}

\begin{abstract}
Japan and Indonesia have developed mutual cooperation in academic exchange programs for the past three decades. Japan acknowledges that student interchange plays a significant role in promoting mutual understanding between Japan and foreign countries. Japanese government expects international students, either those who are still studying in Japan or those who have returned to their home countries, serve as a bridge between their countries and Japan. To achieve this goal, the Japanese government employs some agencies to undertake academic exchange programs. This paper describes these agencies' role in academic exchange programs between Japan and Indonesia. Considering that the Japanese agencies work to promote Japan's soft power through public diplomacy activities under transgovernmental networks model, the author utilizes concepts of public diplomacy and transgovernmental networks as a framework for analyzing the case. The author argues that Japanese agencies have successfully served as Japanese public diplomacy agents by acting great role in advancing Japan's soft power through academic exchange activities. However, some challenges appear in the way to achieve Japanese public diplomacy goal to create mutual understanding between Japanese and Indonesian people.
\end{abstract}

Keywords: Japanese agencies, public diplomacy, academic exchange programs, soft power, transgovernmental networks, mutual understanding.

Jepang dan Indonesia telah mengembangkan kerjasama pertukaran akademik selama tiga dekade terakhir. Jepang mengakui bahwa pertukaran pelajar memainkan peran signifikan dalam mendorong terciptanya kesepahaman bersama antara Jepang dan negaranegara lainnya. Pemerintah Jepang mengharapkan mahasiswa asing, baik yang masih menjalankan studi di Jepang maupun yang telah kembali ke negara asalnya, berperan sebagai penghubung antara Jepang dan negara mereka. Untuk mencapai tujuan tersebut, pemerintah Jepang membentuk sejumlah lembaga yang menangani program pertukaran akademik. Tulisan ini menggambarkan peran JASSO, Japan Foundation, dan JICE dalam program pertukaran akademik antara Jepang dan Indonesia. Mengingat bahwa ketiga lembaga tersebut mempromosikan soft power Jepang melalui aktivitas diplomasi publik dalam kerangka jaringan lintas-pemerintah, penulis menggunakan konsep public diplomacy dan transgovernmental networks untuk menganalisis kasus ini. Penulis berargumen bahwa JASSO, Japan Foundation, dan JICE telah berhasil menjalankan peran sebagai agen diplomasi publik dalam mengembangkan soft power Jepang melalui aktivitas pertukaran akademik. Namun, sejumlah tantangan muncul dalam mencapai tujuan untuk menciptakan kesepahaman bersama antara masyarakat Jepang dan Indonesia.

Kata-kata Kunci: lembaga Jepang, diplomasi publik, program pertukaran akademik, soft power, jaringan lintas-pemerintah, kesepahaman bersama. 
During 60 years of bilateral relations, Japan and Indonesia have developed mutual cooperation in various sectors including academic exchange programs. Since the signing of the Treaty of Peace in April 1958, both countries continue to increase their cooperation not only in inter-state relations, but also in people-to-people interactions. Education sector is believed as one of main sources for strengthening such interactions. The sector has been creating mutual understanding and enhancing close friendship between Japanese and Indonesian people. It is proven by the rise of Indonesian citizens who have been taking part in people exchanges, mainly in academic programs in the past three decades. Most people have been awarded scholarships, either from governments or private sectors.

Japanese government has considered that in the globalized world, the role of people in international relations continues to rise so that diplomacy recently is not only involved state actors, but also non-state actors. This new diplomacy, refers to public diplomacy, puts people as important actors to strengthen bilateral relations. For Japan, public diplomacy has to be about building partnerships, finding commonality, and demonstrating why Japan is a great nation. Prime Minister Shinzo Abe administration has allocated more than US $\$ 500$ million for public diplomacy (Kingston 2015). Based on Ministry of Foreign Affairs of Japan (MOFA Japan 2017), there are six categories of Japanese public diplomacy activities: (1) public relations abroad, (2) dispatches from Japan, (3) cultural exchange, (4) people-to-people exchange, (5) cooperation with international cultural organizations, and (6) cultural grant assistance. These activities are managed to conduct five functions. First, to assist the dissemination of international situation and diplomatic policies in Japan. Second, to inform Japan's domestic situation and its policies to the foreign public. Third, to implement of international agreements to promote cultural exchanges. Fourth, to promote cooperation between Japan and international cultural organizations. Fifth, to help present Japanese culture abroad and promote cultural exchanges with foreign countries.

Japanese public diplomacy is organized by agencies such as Japan Student Services Organization (JASSO), Japan Foundation, and Japan International Cooperation Center (JICE). JASSO works under Ministry of Education, Culture, Sports, Science and Technology (MEXT), whereas Japan Foundation and JICE operate under Ministry of Foreign Affairs. Set up as an independent administrative institution, JASSO comprehensively administers scholarship programs, support programs for international students, and student support programs. The purpose of these programs is to foster the development of creative individuals who will become leaders of society in the next generation, while at the same time to promote international understanding and exchange (JASSO 2018).

Similarly, Japan Foundation aims at deepening mutual understanding between the people of Japan and other countries, cultivating friendship and ties between Japan and the world, and fostering friendship through culture, language, and dialogue. Japan Foundation activities are financed by annual government subsidies, investment revenue, and donations from private sectors. The foundation claims that it is Japan's only institution dedicated to carrying out comprehensive international cultural exchange programs throughout the world (JPF 2018). Japanese MOFA clearly states that the Japan Foundation operate various projects to create Japan's positive images in foreign countries, boost the value of brands throughout Japan while encouraging greater understanding of Japan, and foster pro-Japanese individuals and groups for the future. Japanese MOFA implements the "Japan Brand Program" to pave the way 
for international exchanges through the provision of information on studying in Japan, the establishment of alumni networks of foreign nationals who have studied in Japan, and the grant program for research activities and visiting professors to universities overseas (MOFA Japan 2017).

Exchange programs have also become one of JICE's main activities in recent years. After specifically focusing to strengthen private sector roles and functions in the management of Official Development Assistance (ODA) projects, JICE is currently engaged in a wide range of activities aimed at nurturing human resources across all regions and countries of the world such as managing scholarships for study at higher educational institutions in Japan, conducting international participant training, hosting youth exchange programs, providing Japanese language education and developing its teaching materials, and dispatching interpreters covering multiple languages (JICE 2018).

Unlike JASSO and Japan Foundation which have office in Indonesia, JICE has no branch in the country. Nevertheless, JICE has been collaborating with Indonesian government, schools, and international exchange organizations to conduct Japan East Asia Network Exchanges for Students and Youths (JENESYS) program frequently. This two-week program provides opportunity for Indonesian students and youths to visit Japan for doing exchange with their counterparts in Japan. Similar to JICE, Japan Foundation also offers academic exchange programs such as Japanese Studies Fellowship Program. The foundation's office in Indonesia organizes the program independently by opening call for application and employing committee to select participants. In cooperation with JASSO and Association of Indonesian Alumni from Japan (PERSADA), Japan Foundation conducts Study in Japan Fair annually to provide updated information for Indonesian students regarding Japanese higher education. Additionally, the Japanese MEXT awards Monbukagakusho scholarship annually for Indonesian young talents to study in Japan.

Considering the greater role of non-state actors in public diplomacy, this paper describes Japanese agencies' role in academic exchange programs between Japan and Indonesia. In the first section, the author will explain the relationship between public diplomacy and transgovernmental networks as conceptual framework of this study. In the second section, the author will describe Japanese public diplomacy in general. In the third section, the author will explain the findings regarding the role of Japanese agencies in academic exchange programs between Japan and Indonesia. In the last section, the author will conclude this study.

\section{Public Diplomacy and Transgovernmental Networks}

The author apply public diplomacy and transgovernmental networks as conceptual framework for examining Japanese public diplomacy in Indonesia. Public diplomacy is traditionally considered as the transparent means by which a sovereign country communicates with the public in other countries aimed at informing and influencing audiences overseas for promoting the national interest and advancing its foreign policy goals (Kitano 2007). According to Nicholas Cull (2009), the term "public diplomacy" was coined in 1965 by Edmund Gullion as the process of international communication and cultural relations. It encompasses dimensions of international relations beyond 
traditional diplomacy, the cultivation of public opinion in other countries, the crossborder interaction of private groups and interest, the reporting of foreign affairs and its impact on policy, and the process of intercultural communications.

Hans Tuch (in Gilboa 2008) defined public diplomacy as government's process of communicating with the foreign public to bring understanding for its nation's ideas and ideals, its institution and culture, as well as its national goals and policies. Additionally, Malone (in Hill 2003) considered public diplomacy as the direct communication with foreign people with the aim of affecting their thinking and ultimately that of their governments. Public diplomacy deals with relations among governments, organizations, and individuals of different countries to better serve a nation's policy. Public diplomacy can be called people's diplomacy or people-to-people diplomacy in some countries. Although it is difficult to define which diplomacy (public, state, or other kinds of diplomacy) is the most effective, public diplomacy is not only supplementing other kinds of diplomacy, but also surpasses them in a certain case (Thu 2013). According to Eytan Gilboa (2008), while old public diplomacy relies on advocacy and propaganda, the new one aims at branding and network.

Referring to Gilboa (2008), the new public diplomacy lies on two activities, branding and networking. Instead of prestige and international image, nation branding is essential for a country, and it is cultivated by deploying soft power resources to communicate with and attract the public of other countries, rather than merely their government (Nye 2008; Cull 2009; Lee and Melissen 2011). Soft power is the ability to affect others to obtain the outcomes one wants through attraction rather than coercion or payment (Nye 2008). It can be referred as co-optive power, the ability to shape the preferences of others. Instead of using coercion, soft power embraces attraction and influence. Therefore, soft power can be called as attractive power, an important source of power. A country uses its culture, values, and foreign policy as the three major instruments of soft power. It is more probable for a country to expand its soft power when its culture includes universal values and its policy promotes interest shared by other states. By using soft power, a country can get credibility, legitimacy, and efficacy. As the crucial resource of soft power, credibility shouldn't be destructed. If people believe nation's objectives to be legitimate, they are more likely persuaded to follow without using threats. With the ability to attract and persuade, soft power can increase state's legitimacy (Nye 2004).

In promoting its soft power, a country can use public diplomacy through five methods: (1) listening, (2) advocacy, (3) exchange programs, (4) cultural diplomacy, and (5) international broadcasting (Cull 2008). Listening is collecting and collating data about public and their opinion overseas and using that data to redirect its policy. Advocacy is undertaking an international communication activity to actively promote particular policies, ideas, or general interest in the minds of a foreign public. Cultural diplomacy is making cultural resources and achievements known overseas and/or facilitating cultural transmission abroad. Exchange diplomacy is sending citizen overseas and reciprocally accepting citizens from overseas for a period of study and/or acculturation. International broadcasting is using radio, television, and internet to engage with the foreign public.

In addition, there are three dimensions of public diplomacy which play an important role to create a country's attractive image: (1) daily communication, (2) strategic communication, and (3) the development of lasting relationships through scholarships, 


\section{A. Safril Mubah}

exchanges, trainings, seminars, conferences, and access to media channels (Nye 2008). It is clear that exchange programs are part of public diplomacy activities. Exchanges will exert more impacts on participants. With their personal experience during and after participating in exchange activities, participants can have positive or negative views about the host country. The host country expects that participants have a positive view on the country (Thu 2013). Since academic exchange programs are generally viewed as long-term elements of strategically minded public diplomacy, the programs are thus a cornerstone of public diplomacy. Given that "connecting students across borders is one of the most effective ways of building understanding across nations" (Gates in Whitson 2012), academic exchange programs are enable to develop mutuality, in which both parties benefit (Trost and Wallin 2013).

The new public diplomacy also lies on networking. According to Slaughter and Zarring (2006), networks are informal institutions linking actors across national boundaries and carrying on various aspects of global governance in new and informal ways. They comprise of three types. First, networks of executive officials within established international organizations. Second, networks of officials within the framework of executive agreement. Third, networks of officials that develop spontaneously outside any formal framework like Memorandum of Understanding (MoU) signed by government agencies or other institutions (Slaughter 2004). As the Japanese government agencies, JASSO, Japan Foundation, and JICE are run informally as agents of Japanese public diplomacy by developing networks with other institutions. In Indonesia's territory, they build interrelated connection with government officials, schools, and other academic institutions. They are not diplomat working under ministry of foreign affairs, but today's diplomacy allows them to serve agents of public diplomacy, and along with their counterparts, they likely to create transgovernmental networking.

Transgovernmental network is developed from "transgovernmental relations" which was defined by Robert Keohane and Joseph Nye (1974) as direct interactions among sub-units not controlled or closely guided by the policies of cabinets or chief executives. Facilitated by extensive personal contacts among officials and by conflicts of interest between departments or agencies within modern governments, transgovernmental relations is regarded as an important component of international relations which produces growing interdependence that shapes international outcomes. The most interesting actors in world politics now include the same types of government institutions that are important in domestic politics, such as administrative agencies, courts, and legislatures and the networks they create with one another.

Globalization has opened opportunities for non-state actors to get interacted in international politics. Margaret Keck and Kathryn Sikkink (1998) clearly demonstrate a variety of terms to describe the sphere of international interactions including transnational relations, international civil society, and global civil society. Instead of international civil society or global society, Keck and Sikkink use transnational relations to describe the emergence of various types of non-state actors which play an important role in international realm for the past three decades. Transnational actors like multinational corporations, international scientific organizations, and activist groups can be characterized as forms of transnational networks. Given that JASSO, Japan Foundation, and JICE are operating across nation-state borders and they have established branches in several countries, these Japanese agencies serve as transnational actors that create transnational networks. In Indonesia, particularly, JASSO, Japan Foundation, and JICE have successfully played their role as Japanese 
Japanese Public Diplomacy in Indonesia: The Role of Japanese Agencies in Academic Exchange Programs between Japan and Indonesia

public diplomacy agents by promoting Japan's soft power through academic exchange activities.

\section{Japanese Public Diplomacy}

The origin of Japanese public diplomacy dates back to peace treaty negotiations following the Russo-Japanese war in 1904-1905 when both sides would like to attract the public support from United States (Kitano 2007). The Treaty of Portsmouth formally ended the war was signed in September 1905. It affirmed Japanese presence in South Manchuria, Korea, and the southern half of the Sakhalin Island. Throughout the war and peace talks, American public opinion largely sided to Japan. Japan's effort to get such support marked the adoption of public diplomacy. Yet public diplomacy was actually implemented by the Japanese government following Japan's defeat in World War II. As stated in the Article 9 of Japanese Constitution, the country is prohibited to use military power to wage war. Its constitutional constraints to use hard power makes Japan has no other option except expanding its soft power through public diplomacy (Yasushi and McConnell 2008). Therefore, Japan is considered as the first country in Asia to embrace soft power as the instrument of foreign affairs. The country has more potential soft power than any other Asian countries. The Japanese government has promoted people-to-people exchange in various forms encompassing student exchanges, youth exchanges, and sport exchanges. Student exchanges help promote friendship and goodwill with other countries and gain their understanding toward Japan. University is the main actor of the program. Supported by either state or nonstate actors, academic institutions contribute to public diplomacy by developing their country's soft power that may reinforce with official foreign goals (Nye 2004).

Japan has initiated various youth exchange programs such as JENESYS, Japan and Teaching Program (JTP), Global Youth Exchange Program (GYEP), Ship for Southeast Asian Youth Exchange Program, etc. Japan also offers Monbukagakusho scholarship for studying at Japanese universities. Based on the Outline of the Student Exchange System in Japan published by the Japanese MEXT in 2006, the objectives of academic exchanges are: (1) to promote mutual understanding between Japan and foreign countries and build human networks, (2) to nurture Japanese student with a global outlook and shape an open vibrant society, (3) to internationalize Japanese universities and increase their competitiveness, and (4) to make intellectual contribution to the international community. Japan acknowledges that student interchange, through the hosting and sending of students, plays a significant role in promoting mutual understanding and building strong human networks between Japan and foreign countries. Japan expects international students, including from Indonesia, who return to their home countries serve as a bridge between their countries and Japan. They are expected to increase the intellectual presence of Japan in the international community so that the country can build stable international relations.

\section{Japan's Academic Exchange Programs in Indonesia}

Indonesia and Japan are not in a symmetric situation in human resources development. Even though Indonesia has the highest number of productive age population, the country lacks capable human resources. Indonesia is predicted to have demographic 
dividend when the number of productive age people more than the elderly in 2030 . However, it will become demographic disaster if Indonesia could not manage it properly. In contrast, Japan is categorized as super-aged nation. A summary report of the 2015 National Census showed that the number of elderly people aged 65 or older accounts for 26.7 percent of the 127.11 million total population (Yoshida 2016).

Japan's ageing population will place large strains on the nation's economy and society. The country really needs productive age workers to maintain its high economic performance in the future. Having demographic dividend, Indonesia potentially provides such workers for Japan. Yet the country faces great challenges in human resources development, particularly on the level of education. The highest Indonesian population worked is still in the lowest percentages compared to the other lower education levels. The condition affects the problems of unemployment, underemployment, and poverty. The government's policy to allocate 20 percent budget toward education since 2010 does not fulfill national requirement for higher human resources quality in Indonesia. Therefore, Indonesia should seek the strategic international connections to promote educational exchanges aiming at improving the quality of human resources.

Given that trends and patterns in international students' mobility depend on pushing factors which are conditions in home countries that generate interest in university beyond national borders and pulling factors which are attributes of a host nation that attracts international students to study at certain institutions (Mazzarol 1998). In this case, Indonesian students are encouraged by the government to study in Japan because the country offers high quality educational system. Japan has been so successful in drawing interest of Indonesians to Japanese popular culture that it affects positive image for the Japanese influence. Japanese cultural products have attracted many young Indonesian people. Moreover, Japanese cuisine has been so familiar that Japanese restaurants have been growing in Indonesia (Han 2015). Considering that national governments should be involved in attracting foreign students to study in their countries (Kemp 1995), the Japanese government remains connected to this trend through their agencies. The agencies capitalize on the benefits of international students such as skill migration, economic growth, public diplomacy, and research associated with a knowledge society (Kishun 2007).

As agents of Japanese public diplomacy in Indonesia, JASSO, Japan Foundation, and JICE have been organizing many programs in promoting academic exchanges between Japan and Indonesia. For example, in collaboration with Japan Foundation and PERSADA, JASSO conducted Study in Japan Fair in Jakarta and Surabaya on October 29-30, 2016. This annual event is designed to provide students and educators in Indonesia with updated and reliable information about Japanese higher education and research to help students select an appropriate school and achieve their academic pursuits. Regarding academic exchanges, Japan Foundation offers programs such as Japanese Studies Fellowship Program, Grant Program for Japanese Studies Projects, Grant Program for Intellectual Exchange Conference, Grant Program for International Exchange by Youth and Community Leaders, and Japan Foundation Summer Institute. Furthermore, JICE is in charge of conducting the JENESYS program in cooperation with various local governments, schools, and international exchange organizations in each area. The five-year program (2007-2011) is a project advanced by the Japanese government to provide a sound foundation for strong solidarity within Asia through large-scale youth exchange. During his visit to Indonesia on January 18, 2013, Prime 
Japanese Public Diplomacy in Indonesia: The Role of Japanese Agencies in Academic Exchange Programs between Japan and Indonesia

Minister Shinzo Abe announced to undertake JENESYS 2.0 as a new exchange project to continue JENESYS. The program aims to revitalize Japanese economy by promoting potential interest towards Japan, increasing visitors to Japan, promoting global understanding on Japan's strengths and attractions as well as Japanese values, including Cool Japan (MOFA 2017). The term Cool Japan was coined by Douglas McGray (2002) in his article on Foreign Policy magazine titled “Japan's Gross National Cool" as an expression of Japan's cultural superpower.

In addition, the Japanese government award Monbukagakusho scholarship annually for Indonesian talented youths to study in Japan. In 2013, there were 78 Indonesian students who continue their study to Japan by the support of Monbukagakusho scholarship. The number increased slightly to 104 students in the following year (Japanese Embassy in Jakarta 2014). Japanese Ambassador to Indonesia, Yasuaki Tanizaki mentioned that there are 870,000 Indonesian students learning Japanese language (Simanjuntak 2016). Following the closer Japan-Indonesia relations, Indonesia is expected to send more people to Japan. After completing their studies in Japan, they can join the organization of Japanese alumni in Indonesia namely PERSADA (an acronym of Perhimpunan Alumni Dari Jepang, Association of Indonesian Alumni from Japan). Established in 1963, PERSADA is a volunteer non-profit organization headquartered in Jakarta and 13 branches throughout Indonesia. PERSADA's purpose is maintaining and strengthening relationship with the Japanese people by serving as a bridge between Indonesia and Japan which is expected to provide values required by each party in real term (Martoredjo 2007).

All programs organized by Japanese agencies in Indonesia have successfully contributed to increase the number of Indonesian students in Japan within one decade. In 2006, 643 of 1,488 Indonesian students in Japan got scholarships from the Japanese government. Although the amount was quite low compared to the total number of 121,812 international students who were studying in Japan, it has shown significant rise within ten years. Based on the JASSO report, there were 4,630 Indonesian students residing in Japan in 2016 (Table 1 ). While ranked as $8^{\text {th }}$ biggest country sending its citizens to study in Japan in 2006, ten years later Indonesia was at the top six country contributing to the total number of international students in Japan (JASSO, 2017).

Table 1.

Top Ten Number of International Students in Japan by Nationality

\begin{tabular}{|l|r|r|r|r|}
\hline \multirow{2}{*}{ Country/region } & \multicolumn{2}{|c|}{ Number of students } & \multicolumn{2}{c|}{ Comparison with last year } \\
\cline { 2 - 5 } & $\mathbf{2 0 1 6}$ & \multicolumn{1}{c|}{$\mathbf{2 0 1 5}$} & \multicolumn{1}{c|}{ Number } & \multicolumn{1}{c|}{ \% of total } \\
\hline China & 98,483 & 94,111 & 4,372 & 4.6 \\
\hline Vietnam & 53,807 & 38,882 & 14,925 & 38.4 \\
\hline Nepal & 19,471 & 16,250 & 3,221 & 19.8 \\
\hline Republic of Korea & 15,457 & 15,279 & 178 & 1.2 \\
\hline Taiwan & 8,330 & 7,314 & 1,016 & 13.9 \\
\hline Indonesia & 4,630 & 3,600 & 1,030 & 28.6 \\
\hline Sri Lanka & 3,976 & 2,312 & 1,664 & 72.0 \\
\hline Myanmar & 3,851 & 2,755 & 1,096 & 39.8 \\
\hline
\end{tabular}




\begin{tabular}{|l|r|r|r|r|}
\hline Thailand & 3,842 & 3,526 & 316 & 9.0 \\
\hline Malaysia & 2,734 & 2,594 & 140 & 5.4 \\
\hline Others & 24,706 & 21,756 & 2,950 & 13.6 \\
\hline Total & 239,287 & 208,379 & 30,908 & 14.4 \\
\hline
\end{tabular}

Prime Minister Abe considers Indonesian students as the important asset because Japanese investors in Indonesia can use their language skills for business communication (Idris 2017). With its abundant natural resources and human resources as well as market potential, Indonesia is very strategic partner for Japan. Indonesia currently needs technology and investment, while Japan may need skilled workers to assist millions of Japanese small and medium enterprises to remain competitive (Martoredjo 2007).

However, the rise of Indonesian studying in Japan is not followed by the growth of Japanese students and scholars coming to Indonesia. Most Japanese tend to visit Indonesia just for participating in short-term programs, not for long-term programs such as studying at degree programs or conducting field research. Every year, another Japanese agency, Japan International Cooperation Agency (JICA) undertakes summer exchange program participated by Japanese students. They are students who are interested in international development and responds to their needs for information by conducting discussions with related JICA personnel and observation of JICA project sites (JICA 2017). The exchange program is also organized by university-to-university cooperation. For instance, from September 1 to 28, 2015, 16 Japanese students from Ehima University participated in student exchange at Gadjah Mada University in Yogyakarta, Indonesia. This program is conducted under the MoU signed in 2013 between both universities (UGM 2015). In October 2016, ten Japanese students did voluntary social project in Jenangan Village, Ponorogo, a small town in East Java (IYC 2016).

The number of 4,630 Indonesian students living in Japan is imbalance compared to few numbers of Japanese studying in Indonesia. According to Indonesia's Ministry of Research, Technology, and Higher Education (2017), there are only 217 Japanese students who are currently studying in Indonesia. The fact that there is more outbound Indonesian student to Japan than inbound Japanese students to Indonesia shows that Japan is more attractive than Indonesia in promoting its soft power. Based on the 2018 Global Ranking of Soft Power published by USC Center on Public Diplomacy (2018), Japan and Indonesia are ranked at the first and the ninth respectively across Asian region. As the most attractive nation in Asia, Japan has multiple soft power resources such as the world class higher education institutions, stable economic development, etc. as pulling factors which attract foreigners and various agencies overseas to promote Japan worldwide. Japan has five universities in top 100 of QS University World Rankings 2018, namely University of Tokyo $\left(28^{\text {th }}\right)$, Kyoto University $\left(36^{\text {th }}\right)$, Tokyo Institute of Technology $\left(56^{\text {th }}\right)$, Osaka University $\left(63^{\text {rd }}\right)$, and Tohoku University $\left(76^{\text {th }}\right)$. In contrast, there are no Indonesia's higher education institutions in the list of 100 best universities on the globe. Such situation leads Indonesia to not highly rely its soft power investment in Japan on education but on distinctively aspects of culture. Unlike Indonesian students in Japan who take various subjects offered by Japanese universities like science and technology, medicine, arts and humanities, language and cultural studies, etc., Japanese students in Indonesia prefer to learn Indonesian 
language and culture.

Consequently, the Japanese government could not rely its interest for promoting soft power on Japanese students in Indonesia. Otherwise, Japan expects Japanese alumni organization in Indonesia such as PERSADA to introduce not only Japanese educational system, but also Japanese values. Yet few Japanese alumni joining the organization or other organizations related to Japan. Instead of promoting Japanese values, most of returned Indonesian students do not take Japan into their consideration except for getting a degree from Japanese universities. Even though they are awarded scholarships from Japan, it is not their responsibility to support the Japanese government for promoting Japanese values since their interest is only to pursue master or doctoral degree in Japan. Given this fact, it would be challenging for Japanese agencies in Indonesia for creating two-way mutual understanding between Japanese and Indonesian people as expected by the implementation of academic exchange programs.

\section{Conclusion}

This study finds that Japanese agencies such as JASSO, Japan Foundation, and JICE have successfully played their role to introduce Japanese educational system to Indonesian students and attract them to study in Japan. It is proven by the increasing number of Indonesian students in Japan over the past decade. However, it does not indicate that goals for creating mutual understanding have been successfully achieved. Mutual understanding should be applied in two-way interactions between Japanese and Indonesian people. It would be challenging to achieve this goal if Japanese agencies merely focus on attracting Indonesian people to study in Japan.

Overall, this study finds two existing problems in Japan-Indonesia academic exchange programs. First, the number of Japanese and Indonesian people participating in the programs is unequal. The few numbers of Japanese coming to Indonesia causes Japanese cultural soft power are not fully promoted in Indonesia. Moreover, Indonesian students living in Japan do not have a willingness to introduce Japan to Indonesian society once they return to their home country. Second, even though the Japanese government have awarded scholarships to Indonesian students and scholars, but some perceive that there is Japan's interest to invest its soft power in Indonesia. Consequently, they study in Japan only for obtaining certain degree, ignoring the goal of academic exchange programs to create mutual understanding or ultimately deepen Japan-Indonesia relations.

Hence, the Japanese government faces following challenges. First, encourage more Japanese people to get involved in academic exchange programs. Japan should not only invite Indonesian people to participate academic programs in its country, but also send its citizens to Indonesia. Second, provide understanding to all scholarship awardees about the strategic role of academic exchanges as a bridge for enhancing people-to-people interactions and Japan-Indonesia relations. Japan needs to maintain its connection with scholarship awardees while they are studying in Japan and after they graduate. 


\section{A. Safril Mubah}

\section{Acknowledgement}

This paper is the final report of the Sumitomo Foundation's Japan-related Research Project. The author thanks the Sumitomo Foundation for providing grant to the research project.

\section{References}

\section{Books and Book Chapters}

Cull, Nicholas, 2009. Public Diplomacy: Lesson from the Past. Los Angeles: Figueroa Press.

Hill, Christopher, 2003. The Changing Politics of Foreign Policy. Basingstoke: Palgrave Macmillan.

Keck, Margaret E. and Kathryn Sikkink, 1998. "Transnational Advocacy Networks in International Politics: Introduction," in Activists Beyond Borders: Advocacy Networks in International Politics. Cornell University Press, pp. 1-38.

Kemp, Stephen, 1995. The Global Market for International Students. Adelaide: University of Adelaide.

Kitano, Mitsuru, 2007. "What Is Public Diplomacy?," in Kaneko, Maafumi and Mitsuru Kitano (eds.), 2007. Public Diplomacy. Tokyo: PHP.

Nye, Joseph S., 2004. Soft Power: The Means to Success in World Politics. New York: Public Affairs.

Slaughter, Anne-Marie, 2004. A New World Order. Princeton, New Jersey: Princeton University Press.

Trost, Katrina and Matthew Wallin, 2013. Academic Exchange: A Pillar of American Public Diplomacy. Washington: American Security Projects.

Yasushi, Watanabe and David McConnell, 2008. Soft Power Superpowers: Cultural and National Assets of Japan and the United States. New York: M.E. Sharpe.

\section{Journal Articles}

Gilboa, Eytan, 2008. "Searching for a Theory of Public Diplomacy," Annals of the American Academy of Political and Social Science, 616 (1): 55-77.

Keohane, Robert O., and Joseph S. Nye, 1974. "Transgovernmental Relations and International Organizations," World Politics, 27 (1): 39-62.

Kishun, Roshen, 2007. "The Internationalization of Higher Education in South Africa: Progress and Challenges," Journal of Studies in International Education, 11 (3/4): 455-469.

Mazzarol, Tim, 1998. “Critical Success Factors for International Education Marketing,” 
Japanese Public Diplomacy in Indonesia: The Role of Japanese Agencies in Academic Exchange Programs between Japan and Indonesia

International Journal of Educational Management, 12 (4): 163-175.

McGray, Douglas, 2002. “Japan's Gross National Cool,” Foreign Policy, May-June, No. 130: 44-54.

Nye, Joseph, 2008. "Public Diplomacy and Soft Power," Annals of the American Academy of Political and Social Science, 616 (1): 94-109.

Slaughter, Anne-Marie and David Zaring, 2006. "Networking Goes International: An Update," Annual Review of Law and Science, 2: 211-229.

\section{Government Report}

Japanese Ministry of Education, Culture, Sports, Science and Technology, 2006. Outline of the Student Exchange System in Japan. Tokyo: MEXT Japan.

\section{Online Articles}

Gusti, 2015. "16 Mahasiswa Jepang Ikuti Program Pertukaran Mahasiswa di UGM", Universitas Gadjah Mada (UGM), September 2 [online]. in https://www.ugm. ac.id/id/berita/10377-16.mahasiswa.jepang.\%20ikuti.program.pertukaran. mahasiswa.di.ugm (accessed June 26, 2018).

Idris, Muhammad, 2017. "Banyak Orang RI Belajar Bahasa Jepang, Shinzo Abe: Itu Aset Penting”, Detik, January 15 [online]. in https://finance.detik.com/beritaekonomi-bisnis/d-3396522/banyak-orang-ri-belajar-bahasa-jepang-shinzoabe-itu-aset-penting [accessed June 26, 2018].

Indonesia's Ministry of Research, Technology, and Higher Education, 2017. "Perguruan Tinggi Indonesia Diminati Mahasiswa Asing”, May 12, [online]. in https://ristekdikti.go.id/ perguruan-tinggi-indonesia-diminati-mahasiswa-asing-2/\#CIIevrIZKhuiZWyG.99 [accessed October 15, 2017].

International Youth Cooperation (IYC), 2016. "Japanese Students in Jenangan, Indonesia” October 4 [online]. in https://iyouthc.org/2016/10/04/volunteeringin-indonesia/ [accessed June 26, 2018].

Japan Foundation, 2018. "About Us" [online]. in (http://www.jpf.go.jp/e/about/index.html) [accessed June 24, 2018].

Japan International Cooperation Agency (JICA), 2017. "Japanese Youths Visit JICA Sites in Indonesia” [online]. in https://www.jica.go.jp/indonesia/english/office/ others/peopleo4.html [accessed June 26, 2018].

Japan International Cooperation Center (JICE), 2018. "Who We Are" [online]. in https://www.jice.org/en/about/index.html [accessed June 24, 2018].

Japan Student Service Organization (JASSO), 2017. "International Students in Japan 2017" [online]. in https://www.jasso.go.jp/en/about/statistics/intl_student/ data2017.html [accessed June 9, 2018]. 
, 2018. "About JASSO" [online]. in https://www.jasso.go.jp/en/about/organization/index. html [accessed June 24, 2018].

Quacquarelli Symonds, 2018. "QS World University Ranking, 2018” [online].in https:// www.topuniversities.com/university-rankings/world-university-rankings/2018 [accessed January 29, 2019].

Kingston, Jeff, 2015. "Japan's Public Diplomacy is Expensive and Errant", The Japan Times, February 14 [online]. in http://www.japantimes.co.jp/ opinion/2015/02/14/ commentary/japans-public-diplomacy-expensiveerrant/\#.WQbakcYlHIU [accessed May 1, 2017].

Martoredjo, Sidharta, 2007. "PERSADA, the Domestic Partner of Japan / ASCOJA, the ASEAN Region Partner of Japan" [online]. in http://www.studyjapan.go.jp/ en/ath/atho3e_06.html [accessed June 9, 2018].

Ministry of Foreign Affairs of Japan, 2017. “Japan's Foreign Policy to Promote National and Worldwide Interests" [online]. in https://www.mofa.go.jp/policy/other/ bluebook/2017/html/chapter3/c030402.html [accessed June 26, 2018].

Simanjuntak, Martha Herlinawati, 2016. "Jumlah Orang Indonesia Bejalar Bahasa Jepang Terbanyak Kedua Dunia”, Antara News, January 27, [online]. in https:// www.antaranews.com/berita/542342/jumlah-orang-indonesia-bejalar-bahasajepang-terbanyak-kedua-dunia [accessed June 26, 2018].

USC Center on Public Diplomacy, 2018. "The Soft Power 30: The Global Ranking of Soft Power, 2018' [online]. in https://softpower30.com/wp-content/ uploads/2018/07/The-Soft-Power-30-Report-2018.pdf [accessed January 29, 2019].

Whitson, Brian, 2012. "W\&M Chancellor Makes the Case for International Education," May 31 [online]. in http://www.wm.edu/news/stories/2012/wm-chancellormakes-the-case-for-international-education123.php [accessed June 6, 2017].

Yoshida, Reiji, 2016. "Japan Cencus Report Shows Surge in Elderly Population, Many Living Alone", The Japan Times, June 29 [online]. in https://www.japantimes. co.jp/news/2016/06/29/national/japan-census-report-shows-surge-elderlypopulation-many-living-alone/\#.WzGR-EiFPIU [accessed June 24, 2018].

\section{Unpublished Paper}

Han, Seungik, 2015. "Indonesia, Japanophile: Japanese Soft Power in Indonesia," unpublished paper. 
Japanese Public Diplomacy in Indonesia: The Role of Japanese Agencies in Academic Exchange Programs between Japan and Indonesia 